\title{
Lovende kursendring for LAR-behandling
}

\author{
Den nye forskriften om legemiddelassistert rehabilitering trådte i kraft 1.1. 2010. Den legger \\ til rette for et tett samarbeid mellom spesialisthelsetjenesten og fastlegen. Fastlegen kan \\ nå få delegert mye av behandlingsansvaret. Det var på høy tid med en slik kursendring slik \\ at dødeligheten kan bli redusert.
}

Den nye forskriften må ses som et virkemiddel for å normalisere behandlingen av denne pasientgruppen (1). Retten til legemiddelassistert rehabilitering (LAR) vurderes av et eget rettighetsorgan, nå forankret $\mathrm{i}$ helseforetakene. Forskriften legger opp til et tettere samarbeid mellom dette organet og pasientens fastlege.

Det var først i 2004 at de opiatavhengige i likhet med andre rusavhengige fikk pasientrettigheter. Før denne tid var det lov om sosiale tjenester som var rådende. Mye tyder på at nettopp rettighetsvurderingen har vært altfor strengt regulert og at mange derfor i mange år er blitt henvist til å forsøke ulike former for avrusning eller fortsette sitt misbruk. Reduksjon i dødelighet kan etter min mening bli en etterlengtet gevinst dersom samarbeidet mellom det rettighetsvurderende LAR-organet og fastlegen blir en realitet, og fastlegen får nødvendig erfaring med substitusjonsbehandling i egen praksis.

\section{Avrusning og helserisiko}

Det er dokumentert at særlig avrusning medfører klart økt helserisiko og økt dødelighet. En fersk studie med 276 norske stoffmisbrukere viste en 16 ganger økt dødelighet etter avrusning av opiatavhengige (2). At avrusning ikke er en risikonøytral behandling, men medfører klart økt helserisiko er rapportert også tidligere. Dette har sammenheng med to forhold som kjennetegner denne form for avhengighet. Det første er at toleransen reduseres ved avrusning, dvs. man tåler langt mindre heroin. Det andre er at ønsket om å innta stoffet har vist seg å være en varig endring for dem som har en etablert avhengighet. Avrusning skaper dermed stor fallhøyde og er en behandlingsform med høy risiko. Dette er to grunner til den høye dødeligheten vi har i Norge. Når tilgangen til substitusjonsmedikament blir gjort vanskelig og tilbud om avrusning i fengsel, psykisk helsevern, avrusningsinstitusjoner er svært tilgjengelig, utsettes mange opiatavhengige for unødig helserisiko.

Den nye norske studien viser etter mitt skjønn at andelen som kommer til opiatavrusning består av en altfor høy andel pasienter som får feil behandling (2). Mange av disse bør antakelig tilbys substitusjonsbehandling og ikke avgiftning. På denne måten vil man trolig kunne redusere antall overdosedødsfall.

\section{Politisk kursendring på høy tid} Mye taler for at det er feilaktig å knytte politiske målsettinger om rehabilitering og strenge regler om atferd samt krav om lang tids bruk (mange år) til tilgang til substitusjonsmedikamenter. Resultatet av denne behandlingsfilosofien kommer trolig til uttrykk i den norske overdødeligheten som representerer mer enn 2000 trolig unødvendige dødsfall i perioden 1998-2010 (3).

Det er grunn til å tro at mange liv ville blitt spart om substitusjonsbehandlingen var blitt normalisert og den politiske kursendringen hadde kommet tidligere.

Problemstillingen ble debattert på en internasjonal legemiddelkonferanse i Zagreb i mai 2010 (4). Den store variasjonen i nasjonale strategier gjør opiatavhengighet og mortalitet til et område som egner seg godt for sammenliknende forskning mellom land. Av denne grunn omtales Europa som et laboratorium for narkotikapolitiske tiltak (5).

\section{Samarbeid med fastlegene}

Den nye forskriften for legemiddelassistert rehabilitering gir leger i spesialisthelsetjenesten rett til å skrive inn/ut pasienter i substitusjonsprogrammene. Den innbyr også til samarbeid med fastlegene $i$ tråd med den anbefaling jeg kom med høsten 2009 (6).

I februar 2010 kom en gjennomarbeidet oversiktsartikkel om farmakoterapi og opiatavhengighet. Den gir en kortfattet kunnskapsbasert tilnærming til behandlingen av opiatavhengighet og kan utgjøre et vitenskapelig fundament for behandlingsprogram og nasjonale strategier (7).

Når endringene nå etter hvert skal settes ut i livet er det viktig å gå spesielt kritisk gjennom indikasjonen for såkalt opiatavrusning. Det bør være særlig strenge regler for å akseptere pasienter til gjentatt opiatavrusning, og man må sikre massiv oppfølging etter slik behandling. Det bør også være helt klare begrensninger på hvor mange ganger man kan få forsøke slik avrusning, fordi dødeligheten er så altfor høy nettopp blant dem som gjennomfører opiatavrusning.

Straks pasienten er blitt rettighetsvurdert, bør substitusjonsbehandlingen starte i samarbeid med fastlege, om fastlege ikke allerede har startet substitusjonbehandling slik det er anledning til. Enkle former for opiatavhengighet kan trolig med fordel behandles kun av fastlege i samråd med lege i spesialisthelsetjeneste. Mer kompliserte former med tillegg av psykisk lidelse vil trolig måtte behandles i rushelsetjenesten slik tilfellet er i dag.

\section{Substitusjonsbehandling intet nederlag}

Overgangen mellom nedtrapping og substitusjonsbehandling bør være fleksibel og alltid gjøres i samråd mellom pasient, fastlege og spesialisthelsetjeneste. En skadereduserende tanke må være selve grunnpilaren for pasienter med etablert opiatavhengighet $\mathrm{i}$ henhold til ICD-10/DSM-IV.

Som profesjonelle behandlere bør vi ikke se det som et nederlag om pasienten skulle velge substitusjonsbehandling - men nettopp som et skadereduserende tiltak som vil kunne gjøre noen pasienter mer tilgjengelig for andre typer intervensjoner og psykososial oppfølging.

\section{Bengt Eide-Olsen \\ eide_olsen_bengt@hotmail.com \\ Sollien 53 \\ 5096 Bergen}

Oppgitte interessekonflikter: Forfatter har fătt reise og opphold dekket av Schering Plough i forbindelse med en konferanse om opiatavhengighet.

\section{Litteratur}

1. Forskrift om legemiddelassistert rehabilitering (LAR-forskriften). www.lovdata.no/cgi-wift/ ldles?doc=/sf/sf/sf-20091218-1641.html (19.5.2010).

2. Ravndal E, Amundsen EJ. Mortality among drug users after discharge from inpatient treatment: an 8-year prospective study. Drug Alcohol Depend 2010; 108: 65-9.

3. Haraldsen M. Fastlegen og heroinmisbrukeren Tidsskr Nor Legeforen 2010; 130: 16

4. 9th European Congress on heroin addiction and related clinical problems. European Opiate Addiction Treatment Association. www.europad.org/ europad2010 programme.htm (19.5.2010).

5. Eide-Olsen B. Viktig rapport om narkotika. Anmel delse av: Europeisk overvåkningssenter for narko tika og narkotikamisbruk. Narkotikasituasjonen i Europa. Tidsskr Nor Legeforen 2010; 130: 529-30.

6. Eide-Olsen B. Et politisk bestillingsverk. Tidsskr Nor Legeforen 2009; 129: 2260-1.

7. Lobmaier P, Gossop M, Waal H et al. The pharmacological treatment of opioid addiction - a clinical perspective. Eur J Clin Pharmacol 2010; 66 . $537-45$.

Manuskriptet ble mottatt 11.5. 2010 og godkjent 4.6. 2010. Medisinsk redaktør Erlend Hem. 